\title{
DIPLOMATIC NARRATIVES ON SCIENCE, TECHNOLOGY AND INNOVATION: POWER, COOPERATION AND PERSPECTIVES FROM BRAZIL AS A DEVELOPING COUNTRY ${ }^{1}$
}

\section{Narrativas diplomáticas em ciência, tecnologia e inovação: poder, cooperação e perspectivas do brasil como país em desenvolvimento}

Iara Costa Leite ${ }^{2}$

Júlia Mascarello ${ }^{3}$

Nicole Aguilar Gayard ${ }^{4}$

\section{Introduction}

Science, technology and/or innovation (STI) are central topics in major international relations agendas, such as development, the environment and security. They are also key to understanding dynamics of international conflict and cooperation since STI influences the power of states in the military and economic realms, as in the case of nuclear competition or by determining the technological level of exports - and therefore the quantity and quality of jobs created at home. Capacities in STI are built not only upon indigenous efforts, but also by identifying and extracting foreign resources, such as knowledge and talents, through collaborative initiatives (KRIGE, 2014; SKOLNIKOFF, 1993).

Among the varied interfaces between STI and international relations, science diplomacy has gained considerable attention over the last years. As a practice, it is associated with the interaction between science

\footnotetext{
${ }^{1}$ We would like to thank the Brazilian Council for Scientific and Technological Development (CNPq/Edital Universal 2016) and the Coordinating Agency for Advanced Training of Graduate Personnel (CAPES/Master Grant, PhD Grant, Professor Visitante no Exterior Júnior) for the financial support without which the research that resulted in this article could not have been realized. We also appreciate contributions to this article made by Augustus B. Cochran III, Felipe Ferreira Marques, and Gabriel Fernandes Pimenta.

${ }^{2}$ Visiting Scholar at the Georgia Institute of Technology and Postdoctoral Researcher at the Institute of International Relations at University of Brasília. Associate Professor at the Department of Economics and International Relations at the Federal University of Santa Catarina. PhD in Political Science from the State University of Rio de Janeiro, Master in International Relations from the Pontifical Catholic University of Rio de Janeiro and graduated in International Relations from the Pontifical Catholic University of Minas Gerais. Email: iaracleite@hotmail.com

${ }^{3} \mathrm{PhD}$ student in the Postgraduate Program in International Relations at the Federal University of Santa Catarina (PPGRI-UFSC). Master in International Relations from the Federal University of Santa Catarina (UFSC). Bachelor in International Relations from the Federal University of Uberlândia (UFU). Email: juliamascarello@hotmail.com

${ }^{4} \mathrm{PhD}$ and Master in Scientific and Technological Policy from the State University of Campinas (Unicamp). Bachelor in International Relations from the University of São Paulo (USP). Email: nicolegayard@gmail.com
} 
and foreign policy (RUFFINI, 2017). As a field of study, science diplomacy is still conceptually and theoretically under-elaborated. There are elementary divergences among analysts, for instance, on which actors it includes - governmental actors and scientists, or also private actors such as startups and entrepreneurs (LEITE; GAYARD, 2019a). Besides, publications authored by practitioners are widely diffused and have been influencing emerging academic elaborations. ${ }^{5}$

This article adopts a different stance towards materials on science diplomacy produced by its practitioners, broadly understood here as those individuals or organizations involved in the practice of science diplomacy (including, for instance, scientists and diplomats): it sees such materials as composed by narratives, rather than scientific categories that describe and analyze social phenomena. ${ }^{6}$ Our focus is on frames and causal perceptions related to STI and international relations as elaborated by diplomats in Brazil, where the authors are based. Together with China, India, Russia and the United States, Brazil has become a central stage for competition between developed countries' science diplomacy initiatives (FLINK; SCHREITERER, 2010).

Our aim is to map and systematize narratives on STI authored by Brazilian diplomats and their connections with international relations. We understand narratives broadly, related to how diplomats perceive STI and associate it with power, development, competition and cooperation in multiple geometries (bilateral, multilateral, North-South, South-South) and sectors (nuclear, economic, environmental etc.).

Understanding narratives on STI developed by diplomats matters because their perceptions influence decision making, though we recognize that other actors are also relevant as practitioners working at the intersection between STI and international relations. We also hope to show how plural visions on international STI relations can be when narratives by practitioners situated in a developing country are accounted for.

This article is exploratory and does not depart from a hypothesis as we are dealing with an emerging field that demands mapping and organizing qualitative data as a necessary step to evolve to explanatory approaches. We believe that the effort made here allows future studies to build on its methodological contributions (as we identify key words and debates that can be used to codify larger sums of materials) and on initial hypotheses and suggestions for future research raised at the end of the article.

After a methodological section, the article presents systematization results in three sections. The first one focuses on narratives on STI as an instrument of power, encompassing discussions on its nature and its distribution across the globe, the challenges faced by Brazil and other developing countries, and normative views on what Brazil should do. The second section focuses on perceptions on international cooperation and

\footnotetext{
${ }^{5}$ Maybe the most visible case is the three science diplomacy categories elaborated by the Royal Society (2010, p. vi) and the American Association for the Advancement of Science (AAAS) - science in diplomacy, or "informing foreign policy objectives with scientific advice"; diplomacy for science, by "facilitating international science cooperation"; and science for diplomacy, that is, "using science cooperation to improve international relations" -, which became a popular trend in policy and in academic discussions.

${ }^{6}$ Scientists of course engage in scientific work in their fields of expertise, but they can also author materials on science diplomacy relying on their practical experience as science diplomats. The latter cannot be considered scientific literature as it is not part of their research expertise. Though there may be differences in pieces authored by different groups of science diplomacy practitioners, this article does not aim at exploring them. It is assumed that literature produced by science diplomacy practitioners, either scientists or diplomats, is not scientific and should not be incorporated a-critically by academic literature.
} 
the role of diplomacy, whereas the third explores narratives on South-South and North-South STI cooperation. Concluding remarks outline our main findings and point to initial hypotheses and agendas for future research.

\section{Methodology}

The methodology consisted on the selection and systematization of narratives authored by Brazilian diplomats. Narratives may be strictly defined as efforts to explain the occurrence of an event through which its authors set forth mechanistic processes or human actions, for instance, to make sense of the transition from a beginning to an end state of reality (SUGANAMI, 2008). In this article we understand narratives more broadly, referring to how diplomats perceive STI and its association, as cause, consequence or otherwise, with different international relations agendas, dynamics and geometries. By approaching diplomatic writings as narratives we follow Pinheiro and Vedoveli (2012) when they question the a-critical incorporation of diplomatic ideas to scholarly analysis.

Two groups of works were reviewed. The first encompassed pieces produced by four ministers of Foreign Affairs from the second half of the 20th century onwards: San Tiago Dantas (1961-1962), Celso Lafer (1992/2001-2002), Luiz Felipe Lampreia (1993/1995-2001) and Celso Amorim (1993-1995/2003-2010). All of them are cited in academic articles ${ }^{7}$ as leading figures representing Brazilian foreign policy paradigms. ${ }^{8}$ Their ideas matter because they influence new generations of diplomats and because they cross fertilize with ideas held by other members of the so-called Brazilian "community of foreign policy", gathering individuals whose perceptions frame political discourse and public opinion (SOUZA, 2008).

Only ministers whose works were found as editable PDFs were considered, allowing search tools to identify excerpts containing the words "science", "technology", "innovation", and their variants, such as "scientists", "scientific", and "technological". Those criteria left out ministers whose relevance is also recognized by scholars and who have important elaborations on STI, such as Araújo Castro, and other state representatives who were crucial in defining Brazil’s STI national and foreign policies, such as Admiral Álvaro Alberto and Ambassador Paulo Nogueira Batista. Nonetheless, the selection aimed at allowing the research feasibility and the review of a second group of diplomats: those who have works on STI. As part of this group we identified 16 Curso de Altos Estudos (CAE) dissertations ${ }^{9}$ that have STI as their main object, ${ }^{10}$ out of which

\footnotetext{
${ }^{7}$ e.g. Hirst and Pinheiro (1995); Lima (1994); Pinheiro (2000); Saraiva (2010).

${ }^{8}$ We did not aim at exploring to which extent different ideas held by the selected ministers on Brazilian foreign policy were reflected on their narratives on STI. That could be an interesting question for future research as long as only works by diplomats who can be clearly situated in the ideological spectrum are chosen.

${ }^{9} \mathrm{CAE}$ dissertations are produced by diplomats as part of a requirement to achieve higher ranks at the Brazilian Ministry of Foreign Affairs.

${ }^{10}$ We have selected CAE dissertations that had STI on their titles as summaries of all dissertations could not be found and as word search tools could be used in a couple of publications only. The fact that most of CAE dissertations were not available as editable PDFs kept us from using qualitative analysis tools during the research.
} 
we were able to access ten. ${ }^{11}$ Articles published in two key diplomatic journals, Cadernos de Política Exterior and Cadernos do IPRI, that had STI as part of their discussions were also mapped and reviewed. ${ }^{12}$

The categories under which narratives were grouped did not emanate from the reviewed works only, as this article's authors have a background formed by previous training and research experiences, including as a research group. ${ }^{13}$ Therefore, the systematization of narratives could not refrain from being guided by key themes, taxonomies and debates discussed in scholarly elaborations on innovation systems and STI policies, dynamics and issues studied by International Relations (IR) - conflict, cooperation, power, asymmetry, security, development and the environment - and the connections between STI and international relations.

One of the ideas IR scholars can hardly escape from when trying to make sense of reality (and of discourses) is the liberal-realist debate. Though STI is not a central IR issue (MAYER; CARPES; KNÖBLICH, 2014; SKOLKINOFF, 1993; WEISS, 2005) ${ }^{14}$ one can still find liberal and realist interpretations in authors who do have STI as a main concern, including those coming from other disciplines, such as STI Policy and History of Science and Technology. On the one hand there are those insisting that international scientific collaboration is, or should be, spontaneous and not guided by states and diplomats (WAGNER, 2008), or that technological advances change the structure of international relations, leading states to cooperate (WEISS, 2005). On the other hand, there are those claiming that the structure of international relations has not changed, that sovereignty still matters (SKOLNIKOFF, 1993), ${ }^{15}$ and, as knowledge is part of the structure of power (STRANGE, 1994), that states will supervise its flows, either stimulating the creation of environments at which it can be acquired (for security or economic purposes) or denying access to certain countries to knowledge already possessed. As put by Krige (2019, p. 13), “[k]nowledge is a national resource, and the art of statecraft lies in defining policies and instruments that help draw the line between what kind of knowledge will be shared with (or denied to) whom." Nonetheless, not all states possess similar capacities to oversee knowledge flows involving its enterprises or scientists (LEITE; GAYARD, 2019b).

\footnotetext{
${ }^{11}$ As we can see in Annex 1, gathering CAE dissertations that have STI in their titles, one of them was published in the 1970s, three in the 1980s, one in the 1990s, five in the 2000s and six until May, 2019, when the literature mapping was concluded. Beyond the scope of this study, that evolution is interesting as an indicator of how recently STI has become a primary topic of reflection (i.e. not secondarily attached to issues such as trade, defense or broader bilateral relations involving Brazil) at Itamaraty (the Brazilian Ministry of Foreign Affairs).

${ }^{12}$ As search tools could be used in diplomatic journals it was possible to map articles that did not necessarily mention STI in their titles, but in which STI appeared as part of their content.

${ }^{13}$ The research group we are part of, Relações Internacionais e Ciência, Tecnologia e Inovação (RICTI), was registered at the Brazilian National Council for Scientific and Technological Development (CNPq) in 2016. RICTI aims at producing research and engaging at extension activities related to areas that connect international relations and STI, such as science, technology and innovation diplomacy and international STI negotiations. More information can be found at ricti.ufsc.br.

${ }^{14}$ The fact that IR has not traditionally focused on STI does not mean that it does not have elaborations on it. For instance, realists recognize the role of STI as a means to accumulate capabilities in economic and military realms (MORGENTHAU, 2003; WALTZ, 1979) and to render a country less dependent on others - e.g. through the discovery of alternative energy resources (Waltz, 1979). Waltz (1979) also states that, on the contrary, the search for STI capabilities can also render a state less powerful (if technological autonomy is chosen to the detriment of competitiveness).

${ }^{15}$ Though according to Sknolnikoff sovereignty still matters, autarchy is not an option in a context marked by the emergence of STI as a key aspect in international relations. As he puts, “a nation's performance in science and technology, vital to its competitive success, is now dependent not only on its indigenous scientific and technological capabilities, but also on its ability to stay abreast of progress in other advanced countries and to use that progress effectively in its own research and innovative activities" (SKOLNIKOFF, 1993, p. 229).
} 
As the object of this study is narratives authored by representatives of states - diplomats - situated in a developing country - Brazil - one could expect that views centered on sovereignty and asymmetry in accessing STI resources would predominate. However, we did not use theoretical discussions such as the one exemplified above as an explanatory base for two reasons: because the research that resulted in this article is exploratory and because testing hypothesis would demand a broader evidence base.

\section{STI as an instrument of power and the challenges face by Brazil as a developing country}

Narratives on STI as an instrument of power are visible among the revised diplomats' works. General discussions hinge on at least two questions - what kind of power and power for whom - and are usually accompanied by a normative take on what Brazil and other developing countries should do.

A first group of narratives connects STI with military power and security issues. Discussions range from the association between technological progress, nuclear weapons and increased global insecurity (SAN TIAGO DANTAS, 2014) to cyber security (BRANDT SANDY, 2018; CARVALHO NETO, 2015; NÓBREGA, $2016)^{16}$ and the connection between technological revolutions and intervention in domestic affairs in areas such as biodiversity (COELHO, 1994).

Narratives on STI and military power hold a critical stance from the point of view of Brazil and other developing countries. Souto Maior (1994, p. 51) relates the control of uranium enrichment technologies to American practices of "sectoral suzerainty", whereas for Lafer (1992) nuclear competition and the control of sensitive technologies hindered the ability of developing countries to access dual technologies that could also be employed for economic development. Barros Netto (1990a) also presents a critical reading of what is perceived as a US-led global control of dual technologies supported by its allies.

Once STI is recognized as a source of military power, unevenly distributed and controlled, diplomats reflect on what Brazil should do. According to Lafer (1992), who headed Itamaraty in 1992, 2001 and 2002, strengthening multilateralism would be crucial for Brazil and other medium and small powers to influence the regulation of sensitive technologies. Nevertheless, there is no consensus on whether Brazil should develop military technologies. San Tiago Dantas (2014), minister of Foreign Affairs in the beginning of the 1960s, states that Brazil should focus on the development of industrial civil technologies, building partnerships with any country that could grant access to them, and pragmatically act as a mediator in disarmament conferences (since, in his view, Brazil would not be able to build enough power in the military realm to compete with great powers). The second position is more visible in Celso Amorim, who headed the Ministry of Foreign Affairs in the 1990s and 2000s, in a context marked by more pessimism towards disarmament negotiations, and later became minister of Defense. According to him, Brazil should be more active in developing dual-purpose defense technologies (AMORIM, 2018).

Besides discussing the military aspects of STI, some narratives associate the latter to economic power. Two groups of ideas could be identified. The first stresses geopolitics and the STI-economic power connection. San Tiago Dantas (2014, p. 132) associates technological resources with economic capabilities

\footnotetext{
${ }^{16}$ Cyber security is only mentioned by the reviewed literature as part of bilateral or plurilateral agreements, and not deeply discussed.
} 
and the latter with "war capacities", "independence" and "bargaining power". Barros Netto (1990b, p. 11) stresses that "the consequence of technological advance is a new division of labor in which technology becomes a determining factor to hegemony". ${ }^{17}$

A second group of narratives on STI as a source of economic power make reference to the economic lexicon itself, associating advances in STI to "economic strength" (SILVA, 2018), "competitiveness" (BARROS NETTO, 1990a; MARZANO, 2011), and “comparative advantage” (BARROS NETO 1990a, 1990b; LAMPREIA, 1993; MARZANO, 2011). Beyond references to economic power, STI is connected with "development" (CRUZ JÚNIOR, 2011; SAN TIAGO DANTAS, 1962) or ideas related to it, such as "progress" (LIMA E SILVA, 1982), the knowledge economy (CRUZ JÚNIOR, 2011; PATRIOTA, 2006; SILVA, 2018), or a "new industrial paradigm" (BARROS NETTO, 1990b).

All narratives converge on the need that developing countries make progress in STI. Ignoring this agenda would deepen their marginalization (BARROS NETTO, 1990b; LAMPREIA, 1993). Catching up requires facing challenges on two fronts, domestic and international, though the weight attributed to each can vary across narratives. ${ }^{18}$ In the case of Brazil domestic challenges are perceived as connected, for instance, with insufficient quantity (FORTUNA, 2005) and quality (CRUZ JÚNIOR, 2011) of public investments in STI, low private sector research and development (R\&D) investments (CRUZ JÚNIOR, 2011; FORTUNA, 2005; LIMA E SILVA, 1982) and "low levels of technical productivity" (SAN TIAGO DANTAS, 2014, p. 108). The national innovation system should be structured in accordance with "local circumstances" (FORTUNA, 2005, p. 4) and there is a need to connect research institutions and enterprises (FORTUNA, 2005; LIMA E SILVA, 1982). Poor coordination between STI policies, and between them and macroeconomic and other policies, is stressed by Barros Netto (1990b), Castro (2017) and Piras (2007), whereas Lima e Silva (1982) mentions lack of coherence between legislation and the declared objectives of technological development as an additional obstacle.

But challenges are not seen as connected with the national innovation system only. A second group of narratives stresses that Brazil's STI development is hindered by developed countries, which would not support any initiative that favors the emergence of competitors (AMORIM, 1994); whose level of penetration in Southern economies makes it impossible for the latter to compete in the production of high added value products (PATRIOTA, 2006); and whose interests are reflected in international regimes such as the patent protection one, and organizations such as the Organization for Economic Cooperation and Development and the World Trade Organization (PATRIOTA, 2006). Coelho (1994) also shows, for the environment case, how regimes draw on scientific knowledge that supports the interests of more powerful countries and attribute the causes of environmental problems to developing countries.

Nevertheless, as will be stressed in the next section, Brazilian diplomats also see international interactions as a site of opportunities for developing countries to advance in STI, though how such

\footnotetext{
${ }^{17}$ All quotes have been translated from Portuguese to English by this article's authors.

${ }^{18}$ Amorim (1994, p. 159), for instance, states that he does not believe that "the main obstacle to [Brazilian] technological development in computing and other sectors, such as fine chemistry or biotechnology, is economic", but "has a political nature and derives from the unwavering willingness of other countries". As an example, he mentions is the US "non-conformist" and "aggressive" position towards Brazilian Informatics Policy in the 1980s.
} 
opportunities are framed and assessed can vary depending on the geometry of STI cooperation - North-South or South-South.

\section{International STI cooperation and the role of diplomacy}

All reviewed diplomats agree that international cooperation is key to promote STI advance and that diplomacy plays or should play an important role in that. Reflecting from the point of view of Brazil as a developing country, international cooperation is seen as critical for assessing financial resources and technologies the country does not possess because of its lower development level (COELHO, 1994; SAN TIAGO DANTAS, 2014. See also Lima e Silva, 1982, who shows the role of the United Nations System in promoting technology transfer to developing countries). Moreover, international STI cooperation is framed as a path to increase scientific and technological autonomy (AMORIM, 1994; 2013; LIMA E SILVA, 1982). Other narratives also stress that international cooperation is crucial for any country or agent wanting to make progress in STI. ${ }^{19}$ One of the reasons is connected with the high costs of research investments, leading even competing companies to collaborate (BARROS NETTO, 1990b).

What is the function of diplomacy in STI cooperation? According to Lampreia (1993, p. 5-6), diplomacy has a key role in "conciliating, in attention to the country's interests, sovereignty and interdependence" and in guaranteeing that Brazil will not isolate itself from irreversible trends related to "a world in which technology and scientific knowledge have broadly overcome the importance of traditional production factors [...] and in which the traditional comparative advantages of countries are altered by the technological qualification of their competitors" (LAMPREIA, 1993, p. 5-6).

Some calibrate the role of Itamaraty and the government in STI policy and cooperation. Carvalho Neto (2015, p. 77) mentions remarks made by the Brazilian then minister of Defense, Jaques Wagner, in Washington, stressing the need that Brazilian and US companies associate to create new defense products and that, as "such initiatives essentially depend on business decisions," the role of the governments is "to guarantee adequate institutional structure for the realization of such partnerships.” Diplomats reflecting explicitly on the so-called "innovation diplomacy" (see Box 1) also seem to confer more emphasis to a balanced, non-centralizing role to be played by the government vis-à-vis other innovation system actors. ${ }^{20}$ Diplomacy has a central role in state planning and in designing development and innovation strategies, but such a role should be fulfilled in partnership with the private sector (CRUZ JÚNIOR, 2011).

What are the challenges faced by Brazilian diplomacy in adapting to STI agendas? We identified narratives on the need to define STI cooperation priorities (FORTUNA, 2005); on the need - and undergoing initiatives - to promote interactions between Itamaraty and other ministries, such as the Ministry of Science and Technology (SENA, 2013), and innovation systems actors in Brazil (SILVA, 2018) and abroad (MARZANO,

\footnotetext{
${ }^{19}$ Amorim (1994), for instance, sees international STI cooperation as relevant in all geometries, including North-North, as in the case of European initiates such as the European Atomic Energy Community and the European Organization for Nuclear Research and their role in promoting autonomous technological development.

${ }^{20}$ For instance, according to Silva (2018, p. 319), “the 'triple helix' state takes both 'inductor' and 'regulation' responsibilities” and stands between "total planification of the innovative activity - by means of direct control over research, development and industrial production - and full retreat in a context marked by free action of economic agents.”
} 
2011); on the need that Itamaraty "better equip[s] itself in order to understand and interpret the dynamics related to STI" (PATRIOTA, 2006, p. 62); and on the need that diplomatic management incorporates information technologies (PINTO, 2002).

Box 1 - Narratives on Science and innovation diplomacy

Over the last years some diplomats started making explicit references to science diplomacy (LAFER, 2015), scientifictechnological diplomacy (PATRIOTA, 2006), and innovation diplomacy (CRUZ JÚNIOR, 2011; SILVA, 2018). However, even writings that do not use those terms can implicitly address their practices, such as science in diplomacy, or "informing foreign policy objectives with scientific advice" (ROYAL SOCIETY, 2010, p. vi). San Tiago Dantas (2014) considers "objective knowledge" as key to advise decision-making and solve collective problems. He also mentions the need for precise diagnosis on nuclear capacities as a means to advance in disarmament negotiations (SAN TIAGO DANTAS, 1962).

What is science and innovation diplomacy about in the view of Brazilian diplomats? Lafer (2015) cites the three science diplomacy categories elaborated by the Royal Society (2010): science in diplomacy, needed in a world marked by global challenges related to specific issues, such as climate change and internet governance, and exemplified by the author in environmental and disarmament negotiations he led as a minister of Foreign Affairs; diplomacy for science and the role of cooperation agreements in a context marked by growing scientific networks, exemplified by internationalization processes Lafer was leading as the president of FAPESP; and science for diplomacy and the role of scientific values such as rationality, transparency and universality in solving common problems and promoting international peace.

Other diplomats focus on innovation diplomacy, associated by Cruz Júnior (2011, p. 130, note 30) with "the external role of government and productive sectors... in the formulation and implementation of innovation policies and agendas"; and, by Silva (2018, p. 323), with "diplomatic action in support of the national innovation system". Innovation diplomacy therefore is not connected with the Ministry of Foreign Affairs only, but also with other actors that are part of the innovation system, including academic institutions and the private sector (CRUZ JÚNIOR, 2011; SILVA, 2018).

Silva (2018) distinguishes innovation diplomacy from science diplomacy: whereas the latter assumes that collaboration is a central principle in international relations and a key means to realize national interests, the former stresses that foreign policy decisions must be made according to an assessment of national competitive advantages and that collaboration is a possible strategy to improve innovative capacities, but not the only one (other strategies would include, for instance, economic diplomacy tools aimed at improving a country's position in global value chains). Relying in Jos Leitjen (2017), a Belgian scholar, Silva (2018) states that the principle of competitiveness predominates in innovation diplomacy, as countries compete for assets such as human resources in a context marked by the global diffusion of knowledge and technology.

For Patriota (2006) the changes promoted by science and technology in the last decades require diplomats to adapt. At first they promoted scientific and research exchanges, negotiating agreements and executing joint non-commercial research projects, but recently the agenda has complexified due to the emergence of themes such as internet governance and intellectual property (PATRIOTA, 2006). Current abilities needed by diplomats include gathering more knowledge on STI in other countries and their connections with diplomacy in order to improve decision-making (CRUZ JÚNIOR, 2011). The increasing number of CAE dissertations that have STI as main object in the $21^{\text {st }}$ century (see Annex 1) can indicate institutional efforts in that direction.

Silva (2018), according to whom the purpose of innovation diplomacy is to promote Brazilian high technology abroad and to attract R\&D to Brazil, cites three initiatives that would be part of what he calls a "Brazilian innovation foreign policy": the Science Without Borders Program, created in 2011 to finance scholarships for Brazilian students from technological areas to study in universities in developed countries; the Startout Brazil Program, launched in 2017 as part of a strategy to support the internationalization of Brazilian startups by organizing missions to innovation ecosystems abroad; and the Innovation Diplomacy Work Program, created in 2017 by Itamaraty's Department of Scientific and Technological Themes and aimed at supporting diplomatic missions abroad for exchanges and partnerships between R\&D institutions.

Source: authors' own compilation based on the sources mentioned in the box. 


\title{
North-South and South-South STI relations
}

A rich body of Brazilian diplomatic narratives relates North-South and South-South relations to STI dynamics. North-South relations are seen both as a site of contestations and asymmetries and as necessary for developing countries to catch up or for STI to advance in a context marked by increasing interdependence, though challenges to promote win-win cooperation endure. Part of diplomats who hold a critical stance towards North-South STI collaboration tend to elevate the role of South-South STI relations. However, there are also nuances on South-South narratives, depending on the development level of partner countries.

Framing narratives on STI relations by geometries shows us, first, that STI is perceived as having increased the gap between developed and developing countries, as illustrated by the following quotes:

\begin{abstract}
the industrial revolution has entailed, so rapidly, a shift in life and behavior standards from a certain society that, between the latter and the others, a distance that did not exist in previous times has been established. It was the emergence of modern technology and, consequently, the constitution of new life and production standards that has generated such distancing. Therefore, many states [...] were tremendously marginalized in basic standards of social life (SAN TIAGO DANTAS, 2014, p. 257).

technological progress, in eroding the foundations upon which the classical principle of freedom of navigation relied, has contributed to broaden the inequality level between states in the exploration of ocean resources. The exploration of deep-sea mineral resources is accessible to all countries, but only those that possess technology can effectively undertake it (COELHO, 1994, p. 6).
\end{abstract}

The role of North-South cooperation in promoting STI progress in developing countries is recognized by some (COELHO, 1994; LIMA E SILVA, 1982; LOPES, 1978). A positive stance can be identified, for instance, when the US is presented as a "crucial partner to professional training upgrading and to innovation absorption by Brazilian companies" (CARVALHO NETO, 2015, p. 66). The 2015 US-Brazil defense agreement, which included STI elements, would have evolved from assistencialismo to "cooperation, with mutual, balanced and non-intrusive commitments" (CARVALHO NETO, 2015, p. 75). Even recognizing that inequality in development levels may hinder the distribution of gains, Fortuna (2005) claims that North-South cooperation can benefit both sides, as long as diverse agents are involved, including industries and relying on governmental support.

However, an ambiguity has been identified in narratives of horizontality (real or desired) in NorthSouth cooperation, but at the same time resort to a lexicon that can denote traditional donor-recipient relations, such as "technology transfer" (CARVALHO NETO, 2015; COELHO, 1994; LOPES, 1978). ${ }^{21}$ Similar ambiguities could also been identified in narratives on South-South STI cooperation, mainly in the case of cooperation with less developed countries, where the element of STI exchanges is not central. For instance, according to Sena (2013), when cooperating with countries such as Mozambique and Angola in earth observation, Brazil strengthens their STI capacities as part of a "policy of distributive justice and sharing" (SENA, 2013, p. 4). A tendency to attribute a humanitarian meaning to STI cooperation with less developed countries can also be found in San Tiago Dantas (1962, p. 168) when referring to the role Brazil should play in "providing Bolivian people larger possibilities in the domain of technology".

\footnotetext{
${ }^{21}$ Perhaps that ambiguity can be related to the position occupied by Brazil in international relations as a middle power, whose heterogeneous social and economic structure result in apparently conflicting foreign policy strategies (Lima, 1990).
} 
Such ambiguities are hardly surprising given the economic and STI disparities between Brazil and higher income countries, on the one hand, and lower income ones, on the other. Coherence in narratives on STI cooperation seems to be higher when diplomats refer to relations with countries, groups of countries or regions that have development levels similar to Brazil's. In such cases, one does find a lexicon denoting horizontality and effectiveness. Narratives on Brazil-Argentina cooperation are most conspicuous representations of that, as expressed by the use of the following terms: "pooling of resources, exchange of information, exchange of scientists" (SAN TIAGO DANTAS, 1962, p. 23); "international cooperation based on mutual interests" (AMORIM, 1994, p. 161 referring to biotechnology and computing cooperation); and potentially promoting "autonomy", “independence", "shared heritage" and "effective benefits" (BARTHELMESS, 2016, p. 43, referring to security, defense and advanced technology cooperation).

Though not necessarily with the same emphasis, similar terms can be found in references to Brazil's STI cooperation with Eastern Europe, the Middle East and Mexico (SAN TIAGO DANTAS, 1962), the BRICS (NÓBREGA, 2016), and India (BRANDT SANDY, 2018). In the case of Brazil-China space cooperation, though diplomats tend to hold a positive stance towards it (AMORIM, 1994; BRANDT SANDY, 2018), its asymmetric character can be a challenge, as China is more advanced than Brazil and has been allocating more technical and budgetary resources to their joint satellite program (BRANDT SANDY, 2018).

The importance of South-South cooperation is not highlighted for its STI dimensions only, but also for its political value for counterbalancing international Northern articulations that hinder the access of the South to sensitive technologies (BRANDT SANDY, 2018, referring to the importance of Brazil-China space cooperation); for promoting "the social function of Science in countries marginalized from the innovation process" (PATRIOTA, 2006, p. 178); and for strengthening Southern bargaining power in multilateral negotiations, such as environmental ones, where the political use of science favors the interests of powerful countries (COELHO, 1994).

Finally, when reflecting on Brazil's STI cooperation with other countries, the reviewed pieces mention specific areas, which have been systematized in the box below. 
Box 2 - Countries and áreas

Diplomats refer to specific areas when mentioning Brazil's involvement in STI cooperation in bilateral, plurilateral or multilateral schemes. The figure below exemplifies areas that are cited by some of the reviewed diplomatic works on bilateral STI cooperation with Brazil. One can note, for instance, that biotechnology and related areas are among the mostly mentioned. According to Fortuna (2005) biotechnology has gained attention for its potential for solving global problems. In that context, developed countries have renewed their interests in cooperating with countries such as Brazil because of their biodiversity, research experience and emerging markets. Closely related is the so-called "bioeconomy", the commercial application of biotechnology, a new priority for developed countries. Though Brazil has a comparative advantage in bioeconomy, the very recent and incomplete incorporation of strategies in national institutions and policies, compared to developed countries such as Germany, and insufficient knowledge of its interests in cooperating with different countries and regions can compromise balanced benefits (MASCARELLO, 2020).

Figure 1 - Areas mentioned in bilateral cooperation between Brazil and selected countries

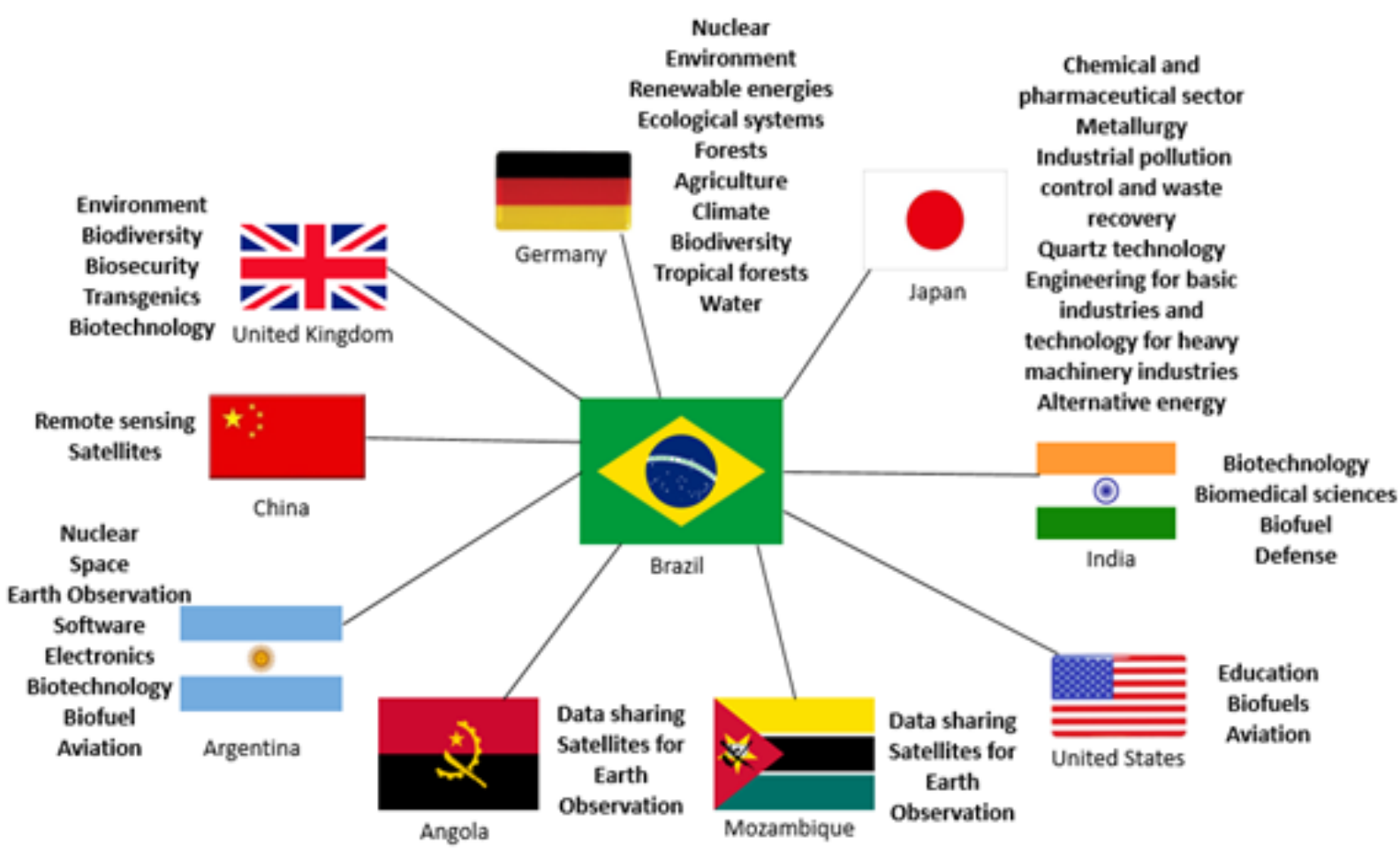

Source: authors' own figure.

The figure was made by identifying some of the areas that are mentioned in Brazilian diplomatic writings that have STI as a central topic. However, we do not know to which extent they reflect real cooperation, as many narratives focus on agreements and not on projects. Lack of knowledge on STI implementation does not mean one cannot draw interesting research questions from analyzing STI agreements and initiatives aimed at guiding their implementation. For instance, by reading Nóbrega's (2016) review of such instruments in the case of the BRICS, one can notice that STI elements are not restricted to STI agreements, working groups or commissions. They are also part of discussions undertaken in other sectors, such as health and defense. One also notices that, when STI appears as a central element in other sectors, China or India lead them, something that can show that these countries confer a more strategic character to STI collaboration than other BRICS members.

In terms of concrete cooperation, some projects or programs are framed by the reviewed publications as successful, such the BrazilArgentina Biotechnology Center (PATRIOTA, 2006), while others are seen as unsuccessful from the point of view of their impact in Brazil. This is the case of Brazil-Germany nuclear cooperation, having transferred a technology whose effectiveness was uncertain and relied in erroneous estimates on Brazil's demands for electric energy (SOUTO MAIOR, 1994). Nevertheless, systematized knowledge on both STI implementation and effectiveness is still scarce overall, as we can see in a study commissioned by the European Directorate-General for Research and Innovation on STI collaboration involving European countries, the US and Japan (FIKKERS; HOVART, 2014). Such knowledge is greatly demanded and, once it is generated and incorporated by diplomatic decisionmaking, management on which areas should be prioritized with each country will certainly improve.

Source: authors' own compilation based on the sources mentioned in the box. 


\section{Final remarks}

This article aimed at mapping and systematizing Brazilian diplomatic narratives on STI and its connections with key international relations issues and dynamics. The first section focused on narratives of STI as an instrument of power - military and economic, but also ideational, as shown by reflections on the ability to inform international regimes with "scientific" evidence. Such power is seen as concentrated in a small group of developed countries. Criticisms are directed towards STI relations, but not to STI itself, which should be pursued by Brazil and other developing countries. Narratives on domestic challenges note a lack of public and private investments and poor coordination between Brazil's national innovation system actors, while narratives on international challenges give emphasis to the power of developed countries, for instance to define regimes that favor the predominance of their interests in STI agendas.

Still, as shown in the second section no one disagrees that international cooperation is crucial to STI progress. The role of diplomacy in promoting effective STI cooperation, from the point of view of Brazil's interests, is stressed by many diplomats, and in some cases, it is possible to find explicit discussions on the role of science, technology and innovation diplomacy. Beyond the role of governmental agencies in promoting international STI cooperation, one can also find narratives attributing a key role to private agents in international collaboration decisions.

The last section systematized narratives on North-South and South-South STI cooperation involving Brazil. Positive stances could be identified in both cases, though diplomats who hold critical views towards North-South relations seem to confer more importance to South-South ones. Ambiguities in narratives were identified in both geometries, as a lexicon denoting assistance predominates in cases involving Brazil's cooperation with more developed as well as with less developed countries (as a receiver of technology in the first case and a provider in the second). Coherence in the use of terms denoting horizontality and cooperation seems to be higher when referring to relations with countries that have similar development levels, and Argentina was the most cited case. In the case of China-Brazil STI cooperation, one finds narratives on both Southern identity and asymmetry.

Compared to positive views on science diplomacy held by Northern practitioner organizations, such as the Royal Society (2010), Brazilian diplomats hold a highly critical stance towards international STI dynamics, which are not seen as neutral. It seems that the apparently emerging preference for the term "innovation diplomacy" reflects such criticism, as the latter assumes competition is a defining element of international relations.

This article resulted from an exploratory research. Future studies can include further exploratory research aimed at mapping narratives on STI held by other diplomats in Brazil and in other countries. Eventually, studies can evolve to hypotheses, for instance on a tendency of state representatives in Southern countries, as revisionists of world order, to hold more critical stances if compared to the ones situated in countries that aim at preserving their power in STI agendas. If confirmed, such hypothesis could corroborate propositions advanced by general theories on international politics (MORGENTHAU, 2003) and approaches to the international behavior of developing countries (ALDEN; MORPHET; VIEIRA, 2010). 
Capturing diplomatic narratives is a first exercise that needs to be complemented by and contrasted with visions held by other governmental (e.g. Ministries of STI and Education) and nongovernmental actors (e.g. science academies and technological entrepreneurs' associations). Grasping agreements and disagreements between them can contribute to gathering more evidence on coordination problems that arise in a context marked by diversification of diplomatic agendas and practices in general (COOPER, 2013) and in Brazil (FARIA, 2012; LIMA, 2000; PINHEIRO; MILANI, 2012). It is also crucial to strengthening alignment between science diplomacy decision-making and implementing actors.

Future studies can also explore differences in North-South and South-South STI narratives. In our study, it was possible to notice an association of cooperation between Brazil and developed countries with STI advance and economic progress, whereas in the case of relations with developing countries, political aspects seemed to predominate. Understanding if that perception holds in the narratives of other practitioners, in Brazil and in other countries, is relevant not only for theoretical purposes. Contrasting such perception with real world evidence can be key to design more effective international STI policies, for instance by supporting initiatives that prioritize transfers and collaboration in sectors with similar levels of technology development, independently of the geometry.

Finally, emerging interpretative frameworks on science diplomacy can be tested and refined by considering the experience of developing countries. Perhaps the most frequent framework is understanding science diplomacy as an instrument of soft power (FLINK; SCHREITERER, 2010; ROYAL SOCIETY, 2010; RUFFINI, 2017), which has been applied to the study of countries that exert such power and not of countries over which such power is exerted.

\section{REFERENCES}

ALDEN, Chris; MORPHET, Sally; VIEIRA, Marco Antônio. The South in World Politics. New York: Palgrave Macmillan, 2010.

AMORIM, Celso. Perspectivas da cooperação internacional. In: MARCOVITCH, Jacques (org.). Cooperação Internacional: Estratégia e Gestão. p. 149-163 São Paulo: Edusp, 1994.

AMORIM, Celso. Discurso proferido no Segmento Intergovernamental de Alto Nível da Conferência Internacional de Biocombustíveis. São Paulo, 20 Novembro 2008.

AMORIM, Celso. Segurança internacional: novos desafios para o Brasil. Contexto Internacional. Rio de Janeiro, v.35, n.1, p. 287-311, 2018. Available at: $<$ http://www.scielo.br/scielo.php?script=sci_arttext\&pid=S010285292013000100010\&lng=en\&nrm=iso>. Access on 24 February 2020.

BARROS NETTO, Sebastião do R. O novo quadro internacional. Cadernos do IPRI. Brasília, n.3, p. 4-17, 1990 a.

<http://www.funag.gov.br/loja/index.php?route=product/product \&path=79\&product_id=565>. Access on 24 February 2020.

BARROS NETTO, Sebastião do R. Desenvolvimento Nacional e Comércio Internacional. Cadernos do IPRI. Brasília, n.5, p. 4-15, 1990b. Available at: <http://www.funag.gov.br/loja/index.php?route=product/product\&path=79\&product_id=570>. Access on 24 February 2020. 
BARTHELMESS, Eugenia. As relações Brasil-Argentina no aniversário da Declaração do Iguaçu. Cadernos de Política Exterior. Brasília, v.2, n.3, p. 27-44, 2016. Available at: <http://www.funag.gov.br/ipri/images/pdf/3.03_Brasil-Argentina.pdf>. Access on 24 February 2020.

BRANDT SANDY, Hudson C. Brasil e Índia: 70 anos de relações bilaterais. Cadernos de Política Exterior. Brasília, v.4, n.7, p. 139-160, 2018. Available at: <http://funag.gov.br/biblioteca/download/cadernos-de-politica-exterior-n-7.pdf>. Access on 24 February 2020.

CARVALHO NETO, Paulino. F. Notas sobre as Relações entre o Brasil e os Estados Unidos. Cadernos de Política Exterior. Brasília, v.1, n.2, p. 63-86, 2015. Available at: <http://funag.gov.br/biblioteca/download/1135_Cadernos_de_Politica_Exterior_Ano1_Num2_Segun do_Semestre_2015.pdf >. Access on 24 February 2020.

CASTRO, André Dunham Maciel S. de. O programa Ciência sem Fronteiras (2011-2016): Um balanço da implementação e do papel do Itamaraty. Tese de Doutorado em Curso de Altos Estudos, Instituto Rio Branco, 2017, 219 p.

COELHO, Pedro M. P. O tratamento multilateral do meio ambiente: Ensaio de um novo espaço ideológico. Cadernos do IPRI. Brasília, n.18, p. 5-46, 1994. Available at: <http://funag.gov.br/loja/download/cadernos-do-ipri-num-18.pdf>. Access on 24 February 2020.

COOPER, Andrew F. The changing nature of diplomacy. In: COOPER, Andrew F.; HEINE, Jorge; THAKUR, Ramesh (eds.). The Oxford Handbook of Modern Diplomacy. Ch. 1, p. 35-53. Oxford: Oxford University Press, 2013.

CRUZ JÚNIOR, Ademar Seabra da. Diplomacia, desenvolvimento e sistemas nacionais de inovação: estudo comparado entre Brasil, China e Reino Unido. Brasília: FUNAG, 2011.

FARIA, Carlos Aurélio Pimenta De. O Itamaraty e a Política Externa Brasileira: Do Insulamento à Busca de Coordenação dos Atores Governamentais e de Cooperação com os Agentes Societários. Contexto Internacional. Rio de Janeiro, v.34, n.1, p. 311-355, 2012.

FIKKERS, Derek Jan; HORVAT, Manfred. Basic Principles for Effective International Science, Technology and Innovation Agreements. Main Report. European Commission, Brussels, 2014.

FLINK, Tim; SCHREITERER, Ulrich. Science diplomacy at the intersection of S\&T policies and foreign affairs: toward a typology of national approaches. Science and Public Policy. Oxford, v.37, n.9, p. 665-677, 2010.

FORTUNA, Luis. F. S. Vasos comunicantes: A política de ciência e tecnologia entre o Brasil e o Reino Unido (1994-2004). Tese de Doutorado em Curso de Altos Estudos, Instituto Rio Branco, 2005, 216 p.

HIRST, Mônica; PINHEIRO, Letícia. A Política Externa Brasileira em Dois Tempos. Revista Brasileira de Política Internacional. Brasília, ano 38, n.1, p. 5-23. 1995.

KRIGE, John. Introduction: Writing the Transnational History of Science and Technology. How Knowledge Moves. In: KRIGE, John (ed.). How knowledge moves: Writing the Transnational History of Science and Technology. p. 1-31. Chicago: The University of Chicago Press, 2019.

KRIGE, John. Technological Collaboration and Nuclear Proliferation: a transnational approach. In: MAYER, Max; CARPES, Mariana; KNOBLICH, Ruth (eds.). The Global Politics of Science and Technology. p. 227-241. London: Springer, 2014.

LAFER, Celso. Relações Internacionais do Brasil (1992). In: LAFER, Celso. Relações Internacionais, Política Externa e Diplomacia Brasileira: pensamento e ação. Ch. 62, p. 865-899. Coleção Relações Internacionais, v. 2. Brasília: FUNAG, 2018. 
LAFER, Celso. Mundo, Ciência e Diplomacia. O Estado de São Paulo. São Paulo, 15 de março de 2015. Available at: < https://opiniao.estadao.com.br/noticias/geral,mundo-ciencia-diplomacia-imp,1651014>. Access on 25 February 2020.

LAMPREIA, Luis F. O Brasil e o atual ordenamento político e econômico mundial. Cadernos do IPRI. Brasília, n.7, p. 5-63, 1993. Available at: <http://funag.gov.br/biblioteca/download/cadernos-do-ipri-num07.pdf>. Access on 24 feb. 2020.

LEITE, Iara C.; GAYARD, Nicole A. Interfaces entre Relações Internacionais e Ciência, Tecnologia e Inovação: um olhar sobre a diplomacia científica. Revista Mundorama. Brasília, v. 13, 2019a.

LEITE, Iara C.; GAYARD, Nicole A. Quatro abordagens sobre a interação entre cientistas e Estados nas Relações Internacionais. Relações Internacionais (R:I). Lisboa, v.62, n.2, p. 85-101, 2019 b.

LEIJTEN, J. Exploring the future of innovation diplomacy. European Journal of Futures Research. Heidelberg, v.5, n.20, p. 1-13, 2017.

LIMA, Maria Regina Soares de. A economia política da política externa brasileira: uma proposta de análise. Contexto Internacional. Rio de Janeiro, v.12, p. 7-28, 1990.

LIMA, Maria Regina Soares de. Ejes Analíticos y conflicto de paradigmas en la política exterior brasileña. América Latina/International. Buenos Aires, v.1, n.2, 1994.

LIMA, Maria Regina Soares de. Instituições democráticas e política exterior. Contexto Internacional. Rio de Janeiro, v.22, n.2, p. 265-304, 2000.

LIMA E SILVA, Francisco. A participação brasileira no sistema das Nações Unidas de Ciência e Tecnologia. Tese de Doutorado em Curso de Altos Estudos, Instituto Rio Branco, 1982, 106 p.

LOPES, José. F. Transferência de tecnologia Japão-Brasil. Tese de Doutorado em Curso de Altos Estudos, Instituto Rio Branco, 1978, 111 p.

MARZANO, Fábio M. Políticas de inovação no Brasil e nos Estados Unidos: A busca de competitividade. Oportunidades para a ação diplomática. Brasília: FUNAG, 2011.

MASCARELLO, Júlia. A cooperação internacional em contextos assimétricos: uma análise da cooperação Brasil-Alemanha em bioeconomia. Dissertação de Mestrado em Relações Internacionais, Universidade Federal de Santa Catarina, 2020, 113p.

MAYER, Max; CARPES, Mariana; KNOBLICH, Ruth. The global politics of science and technology: an introduction. In: MAYER, Max; CARPES, Mariana; KNOBLICH, Ruth (Eds). The Global Politics of Science and Technology. p. 1-38. Londres: Springer, 2014.

MORGENTHAU, H. J. A Política entre as Nações: A luta pelo poder e pela paz. Brasília: Editora Universidade de Brasília: Imprensa oficial do Estado de São Paulo: Instituto de Pesquisa de Relações Internacionais. 2003. 1152p. (Clássicos IPRI).

NÓBREGA, Kenneth. F. H. da. BRICS: de Fortaleza a Goa. Cadernos de Política Exterior. Brasília, v.2, n.4, p. 29-56, 2016. Available at: <http://funag.gov.br/loja/index.php?route=product/product\&product_id=863>. Access on 24 feb. 2020.

PATRIOTA, Guilherme de A. Os Desafios da Diplomacia Científico-Tecnológica Brasileira em um mundo em transformação. Tese de Doutorado em Curso de Altos Estudos, Instituto Rio Branco, 2006, 266 p. 
PINHEIRO, Letícia. Traídos pelo desejo: um ensaio sobre a teoria e a prática da política externa brasileira contemporânea. Contexto Internacional. Rio de Janeiro, v.22, n.2, p. 305-335. 2000.

PINHEIRO, Letícia; MILANI, Carlos (orgs.). Política externa brasileira: as práticas da política e a política das práticas. Rio de Janeiro: FGV Editora, 2012.

PINHEIRO, Letícia; VEDOVELI, Paula. Caminhos cruzados: diplomatas e acadêmicos na construção do campo de estudos de política externa brasileira. Revista Política Hoje. Recife, v.21, n.1, p. 211-254. 2012.

PINTO, João L. de B. P. Política de tecnologia da informação: ferramenta indispensável para a modernização. Tese de Doutorado em Curso de Altos Estudos, Instituto Rio Branco, 2002, 224 p.

PIRAS, José A. G. A relevância da cooperação científica e tecnológica entre o Brasil e a Alemanha no período 1996-2005. Tese de Doutorado em Curso de Altos Estudos, Instituto Rio Branco, 2007, 152 p.

ROYAL SOCIETY. New Frontiers in Science Diplomacy: Navigating the Changing Balance of Power. Policy document 01/10, 2010.

RUFFINI, Pierre. Science and Diplomacy: A New Dimension of International Relations. London: Editora Springer, 2017.

SAN TIAGO DANTAS, Francisco C. Poder Nacional, Cultura Política e Paz Mundial. Rio de Janeiro: Escola Superior de Guerra, 2014.

SAN TIAGO DANTAS, Francisco C. Política Externa Independente. Rio de Janeiro: Editora Civilização Brasileira S.A., 1962.

SARAIVA, Miriam G. A diplomacia científica brasileira e as visões sobre a inserção externa do Brasil: institucionalistas pragmáticos x autonomistas. Revista Mural Internacional. Rio de Janeiro, 2010. Available at: <https://www.e-publicacoes.uerj.br/index.php/muralinternacional/article/view/5285> Access on 01 jun. 2020.

SENA, Davino R. de. O Brasil e a observação da Terra: as tecnologias de sensoriamento remoto como instrumento do desenvolvimento sustentável e seu tratamento pelo Itamaraty. Tese de Doutorado em Curso de Altos Estudos, Instituto Rio Branco, 2013, 212 p.

SILVA, Pedro I. F. da. Fundamentos teóricos e práticos para uma Diplomacia da Inovação. Cadernos de Política Exterior. Brasília, v.4, n.7, p. 3-7-330, 2018. Available at: <http://funag.gov.br/biblioteca/download/cadernos-de-politica-exterior-n-7.pdf>. Access on 24 feb. 2020.

SKOLNIKOFF, Eugene. The elusive transformation: Science, technology, and the evolution of international politics. Princeton: Princeton University Press, 1993.

SOUTO MAIOR, Luiz A. A Diplomacia Econômica Brasileira no Pós-Guerra - Estudo Introdutório. Parte II: 1964-1990. Cadernos do IPRI. Brasília, n.8, p. 5-85, 1994. Available at: $<$ http://funag.gov.br/loja/index.php?route=product/product\&path=79\&product_id=577. Access on 24 feb. 2020.

SOUZA, Amaury de. O Brasil na região e no mundo: percepções da comunidade brasileira de política externa. Rio de Janeiro: CEBRI, 2008.

STRANGE, Susan. States and markets. Londres: Continnum, 1994. 2 ed.

SUGANAMI, Hidemi (2008). Narrative explanation and International Relations: Back to basics. Millenium: Journal of International Studies, v. 37, n. 2, pp. 327-256. 
WAGNER, Caroline. The New Invisible College. Washington, dc: Brookings Press, 2008.

WALTZ, Kenneth Theory of International Politics. Boston, McGraw-Hill, 1979.

WEISS, Charles. Science, technology and international relations. Technology in Society. Amsterdam, v.27, p. 295-313, 2005.

\begin{tabular}{|c|c|c|c|}
\hline Author & Year & Title & $\begin{array}{c}\text { Work } \\
\text { accessed? }\end{array}$ \\
\hline José Ferreira Lopes & 1978 & Japan-Brazil Technology Transfer & Yes \\
\hline Francisco Lima e Silva & 1982 & $\begin{array}{c}\text { Brazilian participation in the United Nations Science } \\
\text { and Technology system }\end{array}$ & Yes \\
\hline José Maurício de Figueiredo Bustani & 1982 & $\begin{array}{l}\text { Marine scientific research from Geneva to Caracas: a } \\
\text { science under suspicion }\end{array}$ & No \\
\hline Vitoria Alice Cleaver & 1988 & $\begin{array}{c}\text { France and the Third World. Twenty years of bilateral } \\
\text { development cooperation. Technical and scientific } \\
\text { cooperation with Brazil }\end{array}$ & No \\
\hline Fernando Jacques de Magalhães Pimenta & 1992 & $\begin{array}{c}\text { Perspectives of Brazil-EEC cooperation in science and } \\
\text { technology }\end{array}$ & No \\
\hline Maria Laura da Rocha & 2000 & $\begin{array}{l}\text { Diplomacy, Technology and Defense: Itamaraty and } \\
\text { the International Collection of Sensitive Technology } \\
\text { for the Aerospace Industry }\end{array}$ & No \\
\hline João Luiz de Barros Pereira Pinto & 2002 & $\begin{array}{l}\text { Information technology policy: an indispensable tool } \\
\text { for modernization }\end{array}$ & Yes \\
\hline Luís Felipe Silvério Fortuna & 2005 & $\begin{array}{l}\text { Communication vessels - The science and technology } \\
\text { policy between Brazil and the United Kingdom (1994- } \\
\text { 2004) }\end{array}$ & Yes \\
\hline Guilherme de Aguiar Patriota & 2006 & $\begin{array}{l}\text { The Challenges of Brazilian Scientific-Technological } \\
\text { Diplomacy in a changing world }\end{array}$ & Yes \\
\hline José Antonio Gomes Piras & 2007 & $\begin{array}{c}\text { The relevance of scientific and technological } \\
\text { cooperation between Brazil and Germany in the period } \\
1996-2005\end{array}$ & Yes \\
\hline Ademar Cruz Júnior da Cruz Júnior & 2011 & $\begin{array}{c}\text { Diplomacy, development and national systems } \\
\text { of innovation: a comparative study between Brazil, } \\
\text { China and the United Kingdom } \\
\end{array}$ & Yes \\
\hline Fábio Mendes Marzano & 2011 & $\begin{array}{l}\text { Innovation policies in Brazil and the United States. } \\
\text { The pursuit of competitiveness. Opportunities for } \\
\text { diplomatic action }\end{array}$ & Yes \\
\hline Cynthia Altoe Vargas Bugané & 2012 & $\begin{array}{l}\text { The Brazil-Korean Relationship in Science, } \\
\text { Technology and Innovation: National Development } \\
\text { Strategies and Prospects for Bilateral Cooperation }\end{array}$ & No \\
\hline Davino Ribeiro de Sena & 2013 & $\begin{array}{l}\text { Brazil and Earth observation: remote sensing } \\
\text { technologies as an instrument of sustainable } \\
\text { development and their treatment by Itamaraty }\end{array}$ & Yes \\
\hline André Dunham Maciel Siaines de Castro & 2017 & $\begin{array}{l}\text { The Science Without Borders Program (2011-2016): A } \\
\text { Review of its Implementation and of Itamaraty's Role }\end{array}$ & Yes \\
\hline Rubem Mendes de Oliveira & 2017 & $\begin{array}{l}\text { MRE, MD and EMBRAER D\&S: Challenges and } \\
\text { Opportunities for Exporting Military Technology to } \\
\text { Developing Countries }\end{array}$ & No \\
\hline
\end{tabular}




\begin{abstract}
Science diplomacy has recently become a buzzword in policy and in academic discussions. Definitions and approaches have been informed by literature produced by practitioners of science diplomacy situated in developed countries. This article maps and systematizes narratives authored by Brazilian diplomats on science, technology and innovation (STI) and their connections with international relations dynamics and issues, such as power, cooperation, development, security and the environment. By addressing pieces produced by practitioners as narratives, rather than as scientific categories that describe and analyze social phenomena, the article explores how STI is perceived and framed by Brazilian diplomats. The methodology included the selection and systematization of publications authored by ministers of Foreign Affairs, in whose diplomatic writings the words "science", "technology", "innovation" and their variants were searched; and pieces on STI produced by career diplomats. Writing from the perspective of Brazil as a developing country, most of reviewed pieces hold a highly critical view towards the international dimensions of STI, which are not seen as politically neutral. However, none of the diplomats disagree on the need for Brazil and other developing countries to build STI capacities as a means to accumulate power and/or to develop. International cooperation on different geometries is seen as crucial for that though perceptions on the effectiveness of North-South and South-South STI cooperation can vary.
\end{abstract}

Keywords: Science and innovation diplomacy; Power; International cooperation.

\title{
RESUMO
}

A diplomacia científica se tornou recentemente um chavão em discussões políticas e acadêmicas. Definições e abordagens têm sido informadas pela literatura produzida por indivíduos e organizações que atuam na prática da diplomacia científica situados em países desenvolvidos. Este artigo mapeia e sistematiza narrativas de diplomatas brasileiros sobre ciência, tecnologia e inovação (CT\&I) e suas conexões com dinâmicas e temas das relações internacionais, como poder, cooperação, desenvolvimento, segurança e meio-ambiente. Ao abordar as obras produzidas por practitioners como narrativas, e não como categorias científicas que descrevem e analisam fenômenos sociais, o artigo explora como a CT\&I é percebida e enquadrada por diplomatas brasileiros. A metodologia incluiu seleção e análise de publicações de ministros das Relações Exteriores, em cujos escritos diplomáticos trechos contendo as palavras "ciência", "tecnologia", "inovação" e seus variantes foram buscados; e obras sobre CT\&I produzidas por diplomatas de carreira. Escrevendo da perspectiva do Brasil como país em desenvolvimento, a maior parte das obras analisadas sustenta uma visão altamente crítica em relação às dimensões internacionais da CT\&I, as quais não são vistas como politicamente neutras. Contudo, nenhum dos diplomatas discorda da necessidade de que o Brasil e outros países em desenvolvimento construam capacidades em CT\&I como meio para acumular poder e/ou se desenvolver. A cooperação internacional em diferentes geometrias é vista como crucial para tanto, embora as percepções sobre a efetividade da cooperação Norte-Sul e Sul-Sul em CT\&I possam variar.

Palavras-chave: Diplomacia da ciência e da inovação; Poder; Cooperação internacional. 


\section{COPYRIGHT:}

Este é um artigo publicado em acesso aberto e distribuição sob os termos da Licença Creative Commons de Atribuição Não-Comercial CompartilhaIgual 4.0 Internacional (CC BY-NC-SA 4.0), que permite seu uso, distribuição e reprodução em qualquer meio, bem como sua transformação e criações a partir dele, desde que o autor e a fonte originais sejam creditados. Ainda, o material não pode ser usado para fins comerciais, e no caso de ser transformado, ou servir de base para outras criações, estas devem ser distribuídas sob a mesma licença que o original.

This is an open-access article distributed under the terms of a Creative Commons Attribution-NonCommercial-ShareAlike 4.0 International License (CC BY-NC-SA 4.0), which permits its use, distribution and reproduction in any medium or format, as well as to transform and build upon the material, provided that the original author and source are credited. Furthermore, the material cannot be used for commercial purposes, and in case it is transformed, or used as bases for other creations, these must be distributed under the same license as the original. 